\title{
THAI BANKING: A NOTE ON TECHNOLOGICAL CHANGE AND TECHNOLOGICAL CAPABILITIES
}

\author{
Jarunee Wonglimpiyarat \\ The National Science and Technology \\ Development Agency (MTEC), Thailand
}

\begin{abstract}
This paper reports on the technological capabilities and learning of Thai banking system. It identifies innovation development of the system as it evolved and how the learning process took place. This study is based on a leading technological regime change literature and the results are based on the study of five commercial banks: Bangkok Bank, Siam Commercial Bank, Thai Farmers Bank (Kasikorn Bank), Krung Thai Bank, and Bank of Ayudhya. Mass automation of work procedures occurred during the 1960s and 1970s while the smart automation regime began in the early 1970s. The ways in which the banks improved their technological capabilities via electronic banking services is explored. The results also show that the use of technology in the mass automation regime is carried through to the smart automation regime, showing that the technological change in the banking sector is not revolutionary, but ocurred slowly, i.e. evoled via slow learing process.
\end{abstract}

JEL Classification: G21

Key words: technological change, technological capabilities, revolutionary, evolutionary, mass automation, smart automation.

\section{Introduction}

There is a wealth of literature on how organisations learn and how technological changes lead to learning but little attention is given to the issues of whether change is perpetrated as evolutionary or revolutionary technological regime changes in banking industry: for a leading article see Buzzacchi et al. (1993), the paper which this study closely follows. Most studies have been concerned with manufacturing sector leading to just few reports on service organisations. It is, therefore, useful to investigate this neglected area relating to banking, which is recognised as an important sector in the use of information 
technology (IT) (Barras, 1990) in that the use of IT plays an important role in accumulating technological capabilities within individual banks. For very good practical reasons, Thai banking has been increasingly challenged by a high degree of IT adoption since IT plays a similar important role, as in other countries as well, in improving the performance of the banking business.

The objectives of this paper in studying the technological capabilities of Thai banking system are:

- To examine the learning concept theories as ways to accumulate technological capabilities by an organisation.

- To test the concepts of technological learning and the technological regime as in Buzzacchi applied to the case of Thai banking.

The research uses acase study methodology to examine the technological capabilities. The case studies (banking in a developing country) are used to test the model, which states that there is a weak evolutionary link between the mass and smart automation regimes, causing the stock of knowledge and skills used in the first to be unusable in the subsequent regime.

The following research questions are the subject of this inquiry:

Q1. Is the technological change in Thai banking evolutionary or revolutionary?

Q2. Can cumulative learning in the mass automation regime be used in the smart automation regime?

The rest of the paper is organized as follows. Section 2 reviews the concepts of learning and technological change - that includes a critical examination of the adopted analytical approach. The theoretical framework on technological accumulation leading to learned capabilities provides a basis for the analysis. Section 3 provides an overview of Thai banking to provide a background understanding of the process of creating technological capabilities. Section 4 presents the analysis of findings using five major commercial banks; the Bangkok Bank (BBL), the Krung Thai Bank (KTB), the Thai Farmers Bank (Kasikorn Bank - TFB), the Siam Commercial Bank (SCB), and the Bank of Ayudhya (BAY). Section 5 ends this paper with suggestion for future research.

\section{Theoretical framework}

\subsection{Review of technological learning concepts}

To understand the learning process, to accumulate technological capabilities of banking, it is necessary first to consider the various concepts of learning that precedes technological change. The learning may be defined in a number of different ways.

According to Bell and Scott-Kemmis (1985), learning concerns the mechanisms and processes which bring about technological progress and innovation. They emphasise the acquisition of additional technical skills and knowledge by individuals and by organisations. Other theorists, such as Senge of MIT and Argyris of Harvard see learning as a collective, diagnostic process. 
Table 1: Alternative concepts of learning in the literature

\begin{tabular}{|c|c|c|}
\hline & Concepts of Learring & Seltolars \\
\hline 1) Leaming & $\begin{array}{l}\text { Acquiring and absorbing knowledge, skills and experience } \\
\text { (which may come to be ased for, and incorporated into any } \\
\text { type of technical clange) }\end{array}$ & $\begin{array}{l}\text { Colsen \& Levinthal (1990), } \\
\text { Amsden \& Hikino (1993) }\end{array}$ \\
\hline 2) Learning & $\begin{array}{l}\text { Implementing a particular type of technical change } \\
\text { ('incremental') }\end{array}$ & $\begin{array}{l}\text { Adler \& Clark (1991), } \\
\text { Bessant \& Buckingham (1993) }\end{array}$ \\
\hline 3) Leaming & $\begin{array}{l}\text { An integrated process iavolviag (2) pins the particalar } \\
\text { kinds of (1) associated with an 'incremental' type of } \\
\text { techaical change }\end{array}$ & $\begin{array}{l}\text { Rosenberg (1982), } \\
\text { Malerta (1992), } \\
\text { Von Hippel \& Tyre (1995) }\end{array}$ \\
\hline 4) Leaming & $\begin{array}{l}\text { An integrated process of impleanenting any type of } \\
\text { technical change plas the acquisition of any types of } \\
\text { knowledge, skill and experience }\end{array}$ & $\begin{array}{l}\text { Dosi (1982), } \\
\text { Freeman \& Perez (1988) }\end{array}$ \\
\hline
\end{tabular}

Table 1 shows the different views of authors on what is meant by learning. Cohen and Levinthal (1990) along with Amsden and Hikino (1992) view learning as the acquisition of knowledge from outside sources while Adler and Clark (1991), including Bessant and Buckingham (1993), view learning as any activity leading to incremental improvement (learning curve improvement). According to Rosenberg (1993), Malerba (1982), and Von Hippel and Tyre (1995), the concept of learning is defined as an integrated process of knowledge acquisition which ultimately enhances the stock of knowledge. However, the last concept of learning according to Dosi and Freeman (1994) is broad since it covers any type of technical change plus the acquisition of any type of knowledge. In this study, the third concept is used in order to suggest that learning is a process of enhancing the stock of knowledge.

Lall (1982) divided the different concepts of learning into elementary, intermediate, and advanced forms. Elementary learning includes basic learning like learning by doing what is stated as in Von Hippel and Tyre (1995) and Arrow (1962). Intermediate learning includes processes undertaken to achieve incremental adaptations and improvements, such as learning by training. Lall refers to advanced learning as the skills and know-how required for carrying out major technological adaptations in both product and process technology, like learning by searching. Yet, there are problems in classifying the degree of increased improvement which some scholars like Freeman and Perez (1988) have tried to do a taxonomy of innovations.

The adoption of different learning mechanisms, to some extent, determines the pace of progress or improvement along the technological trajectory of individual banks. Improvement is not constant over time but depends on a firm's strategy for the allocation of resources. Bell 1984), Malerba 1993), and Hobday (1995) suggest that learning requires resources and is thus a rather costly process. 
At the level of low resource allocation, the learning mechanism includes the neoclassical notion of learning by doing (1962) - a problem-solving process usually plugged into a production function. Lall (1994), Von Hippel and Tyre (1993), and Von Tunzelmann (1995) also view this type of learning as a process of trial and error and problem-solving.

This is in accordance with Rosenberg's view of learning by using, which seems to be a series of minor improvements in sharp contrast to major innovations of Schumpeterian magnitude. Bell argues that improvement in productivity - as represented by learning curve improvement - may have nothing to do with an increase in skill and/or knowledge. However, it is important that this type of learning has involved some element of tacit knowledge since it is tied to the usage or activation of codified knowledge. Tacit knowledge is also a key feature of technological accumulation because a large part of technology is embodied in people and institutions while such knowledge is not easily transferred (see Mansel and When (1998)). Other types of learning which seem to be costless, by-products of doing, include learning by operating and learning by changing.

At the level of greater resource allocation, learning mechanisms include system learning, learning by training, learning by searching and learning by hiring. They are channels calling for intellectual engagement, rather than repetition like doing-based learning. Such progress does not occur passively or constantly through time but is the result of deliberate resource allocation, quite often the result of firms' strategies. However, the capacity to absorb knowledge together with the ability to recognise, assimilate, and use external competencies with a view of incorporating them into internal development seems to be more difficult, particularly in the sense of how to internalise knowledge (absorptive capacity) under certain market conditions. Even so, the development of new competencies cannot be assured through learning mechanisms because learning channels are still difficult to incorporate and 'technologies' are so product-specific (as in Tunzelman (1995).

\subsection{Learning approach - accumulation of technological capabilities}

The term capabilities emphasises the key role of strategic management in the process of adapting, integrating, and re-configurating internal and external organisational skills, resources, and functional competence in a changing environment as in Teese and Pisano (1994). The term technological capability is more technically focused, and has different definitions. For example, Dahlman and Westphal (1982) define it as having the technical knowledge necessary to carry out production engineering projects and create new technology. Lall (1982) defines it as the general ability to undertake a broad range of tasks in the setting up, operating, improving and expanding of production facilities. It seems that these scholars view technological capability as a production function. A wider notion is held by Bell and Pavitt (191993) that the resources needed to generate 
and manage technical change, including the skills, knowledge, and experience are the institutional structures and linkages. I will assume that the resources needed are the ways of learning and assimilation which are far from automatic, requiring extensive commitment to developing technological capabilities.

Lall categorises firm-level technological capabilities into 3 parts: investment capabilities, production capabilities, and linkages capabilities with a focus on manufacturing services. He emphasises that the basic core functions in each major category has to be internalised by the firm to ensure successful commercial operation. This is in accordance with Bell and Scott-Kemmis' view that certain core technological capabilities should be built within the firm and by firm. That is, they should have the ability to make the necessary adaptations to induce a new generation of technology. This means that technological capabilities have their roots in various processes set up by the firm's own efforts and are conditioned by the firm's learning approach.

Such accumulation can be undertaken actively or passively. Active accumulation is an intentional effort to make modifications, adaptations, and improvements to technological activities, as in an empirical case study of learning by training in the Korean petrochemical industry (see Dahlman and Fonseca, 1987) and by searching and training as in the case of the USIMINAS steel plant in Brazil. In contrast, passive accumulation refers to low effort intensity, like passive learning by doing. It has a limited value as a mechanism for technological accumulation and may result in a shallow learning curve. However, the complementarities from these learning processes will yield enhancements to the stock of knowledge according to Bell's learning curve theory.

Teece and Pisano (1994) emphasise path dependencies as factors that can influence the way ahead. In other words, what a firm can do in the future is constrained by what it has been able to do in the past. It appears that the development of technological capabilities is cumulative and dependent on firms' histories. This is in accordance with Nelson and Winter's view that the firm's competence building is path-dependent because it is shaped by its routines. Barras, Bell, Bell and Pavitt (1993) imply that learning is cumulative in character - the learning in one stage is dependent on the learning path in the past. Past learning is not wiped out but provides the foundation for further knowledge to be added to it or to reinforce it in subsequent periods.

Such a view of enhancing knowledge seems to put aside the technologically deterministic view of Buzzacchi et al. who rejects the cumulative nature of learning by arguing that learning in the smart automation regime has nothing to do with learning in the mass automation regime. This nature of things also effaces the demarcation of the separate sets of knowledge identified by them (see further discussed in section 2.3.2) that the shift in technological regime causes a vast chasm of two sets of technological knowledge learnt in the mass and smart automation regime. In this sense, the writer is led to argue that learning is complex 
and multidimensional. Yet in models of economic growth - whether neoclassical or evolutionary - learning is usually reduced to a single feature of a learning curve. Learning is an input which combines with other inputs to set in motion the process of continuing technological capabilities. However, learning is also an output of existing knowledge as well as of activities. New capabilities based on past learning propel more developed capabilities in product and process innovation.

It is clear that a firm's technological capabilities are not only conditioned by its learning approach at the level of the firm. Organisational and institutional levels also pose challenges and opportunities for the sustainability of firms' activities in the continuous production of new developmental knowledge of capabilities. External factors such as infrastructure, government policy and market mechanisms also play a significant role in firms' behaviour. This suggests that the National System of Innovation is important for corporate competitiveness in the sense that it affects the progress of firms, which ultimately results in firmspecific technological capabilities.

\subsection{Technological change and learning implications}

Evolutionary or revolutionary echnological change? The conceptual model of innovation in the banking industry developed by Buzzacchi et al. (1993) is derived from an econometric analysis of Italian commercial banks. They argue that the innovation process in the 'mass automation' regime, coinciding with the automation of back-office procedures, is quite distinct from the 'smart automation' regime that followed, which focused mainly on the provision of Electronic Banking (EB) services; Cash dispenser (CD), Automatic Teller Machine (ATM), Point of sale (POS), Remote banking (RB), Home banking (HB), and Corporate banking (CB). Accordingly, the technical change in banking exhibits revolutionary characteristics triggered by the availability of distributed data processing and data transmission networks.

In the discussion of moving through the regimes, Buzzacchi et al. (1993) and Tushman and Anderson (1986) have in common the view that technical change represents discontinuities between old and new technologies. The Schumpeterian view also emphasises discontinuity. However, Thomas Hughes (a famous US historian of large technical systems) argues that there is no such thing as radical innovation by looking at the evolution of large systems (e.g. electricity networks, teleco networks, and banking networks could similarly be included). In contrast, Freeman and Perez (1988) argue that there are radical technological changes or discontinuities, probably because in their view, technology (e.g. IT) affects the suppliers of components and changes their industrial boundaries. Von Hippel ((1988) argues that innovating is not always radical from the perspective of innovative organisation, that there are incremental improvements through all organisational activities. 
The different views of the conceptual implications arise from consideration from different perspectives. On the one hand, Buzzacchi et al. consider the product level as the unit of analysis (EB consisting ATM, POS, RB, HB) within the product life cycle pattern of product substitution. They consider the development of the microprocessor in the early 1970s as a trigger which progressively enhanced product capacity enabling product innovations and substitutions for prior product/process technologies leading to revolutionary technological change. Buzzacchi et al. on the other hand, interpreted Barras's RPC model as having evolutionary characteristics when applied to the banking sector. They may regard Barras's unit of analysis as the firm level within the context of the innovation life cycle (a progression from process to product innovation) because the RPC model is basically generated from case studies of IT-based service organisations like retail banking, insurance, accountancy, and local government. So, they see the adoption of IT in these organisations as a continuous progression through three stages: improved efficiency, improved quality, and new products, all of which has an evolutionary character.

Although Buzzacchi et al. tried to make a conceptual distinction, the two concepts are not mutually exclusive. Barras's concept of the RPC model as progress from stages of improved efficiency and quality to new products can explain Buzzacchi et al.'s mass automation regime in the sense that the last stage of new products can be seen as a link to Buzzacchi et al.'s smart automation regime, being defined as a radical innovation of Electronic Banking (EB). This suggests that there is no clear-cut distinction between the two regimes, but there is an interrelated period with a smooth progression from one to the other.

Learning accumulation along with the technological change? According to Dosi (1982), the technological trajectory is defined as a pattern of normal problem-solving activity (or progress) along a technological paradigm. Nelson and Winter (1977) define it as the direction towards which the problem-solving activity moves, or as the 'natural trajectories' the of technical progress. Tushman and Anderson describe patterns of technological change as a cumulative process until punctuated by discontinuous innovations. This causeing technological shifts, either competence-enhancing or competence-destroying. Competence-enhancing discontinuities are order-of-magnitude improvements based on cumulative experience in the use of earlier vintages of technology in contrast to competencedestroying discontinuities which require the mastery of new technology, skills, abilities, and knowledge in both the development and the production of the product.

Buzzacchi et al. argues that a shift in the technological regime of the mass automation and smart automation regimes lead to a substantial devaluation of the stock of knowledge and skills accumulated by firms in the previous regime. "One important implication of the change in technological regime is that the 
discontinuity largely canceled out the cumulative effects associated with the path previously followed by technology."

In terms of moving through the regime, Buzzacchi et al. and Tushman and Anderson agree that there is a discontinuity in the technological regime and a shift towards revolutionary change results in competence-destroying. This suggests that they understate the importance of cumulative learning. However, Pavitt (1986) argues that even when there are radical innovations, they rarely displace all the skills and knowledge related to the earlier technological regime.

Buzzacchi et al. considers the development of IT knowledge through the progression from the mass automation regime to the smart automation regime as a weak evolutionary link. However, the investigation of the model shows that this does not represent a weak link, but rather, a strong evolutionary link for the following reasons. First, their conceptual model of innovation can be viewed as technologically deterministic in the sense that they tie the learning process of a firm to the use of new hardware technology. They determine the learning process as dependent on new hardware technology in the sense that the different hardware structure of EB services requires new knowledge to be mastered. In other words, the learning process is dependent on the new hardware technology. It may be true that new technology demands new skills/knowledge but the former knowledge is not totally destroyed.

It is, rather, an interactive process by which the former knowledge is replaced by the new knowledge (the process of continuous learning and enhancement). This suggests that technology is systemic and should not be thought of in isolation. At the same time, the firm has technological choice in selecting new technology compatible with the old technology currently in place in the organisation. Second, their conceptual model of innovation presents a fragmented learning process in the sense that there are two independent regimes demanding different knowledge. When learning in the mass automation regime ends, it recommences in the smart automation regime, causing a technological discontinuity. Even if it is appropriate for Buzzacchi et al. to state their case from the perspective of the product level and then classify the regimes, it seems that there is still a continuous learning process across the regimes. It appears likely that they ignore the importance of the learning that is tacit in nature, embodied in people and institutions in a cumulative way (path dependent). People may not radically change the way they think and interact with others (which is a way of fostering individual learning processes) because such a way involves tapping into people's perceptions based on their own experiences. Insofar as the concept of different technological regimes is concerned, the characteristic of progression seems to be a continuous learning process. 


\section{Overview of Thai banking}

A background of the Thai banking industry at the macro level is shown in Table 2. The major banks in Thailand are the Bangkok Bank (BBL), the Krung Thai Bank (KTB), the Thai Farmers Bank (Kasikorn Bank - TFB), the Siam Commercial Bank (SCB), and the Bank of Ayudhya (BAY). The banking innovations developed gradually through the use of technology. Awareness that technology is vital to competition in banking began when Bangkok Bank introduced interbranch online services in 1970. However, pro-active competition through the use of IT to improve services across the industry did not occur until

Table 2:The highlights of the banking industry in Thailand

\begin{tabular}{|c|c|}
\hline Y년 & 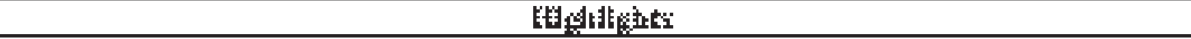 \\
\hline 1:4t: & 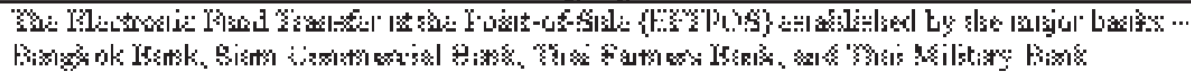 \\
\hline 190 & 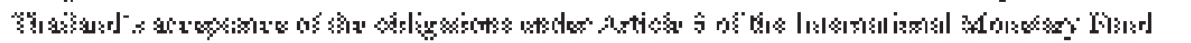 \\
\hline Fitly $10 \%$ & 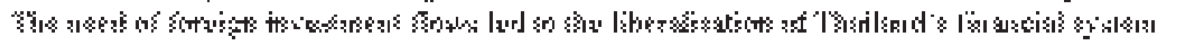 \\
\hline 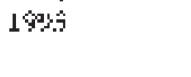 & 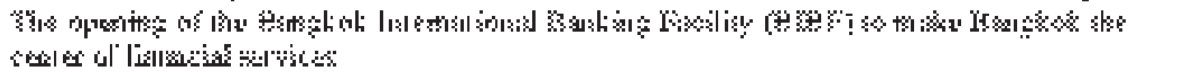 \\
\hline 199 & 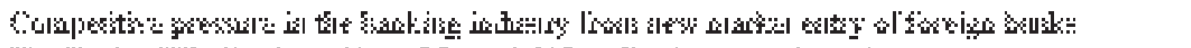 \\
\hline 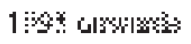 & 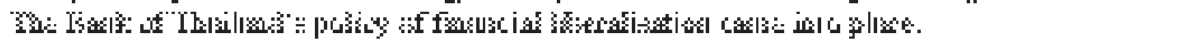 \\
\hline $1 \% 9$ & 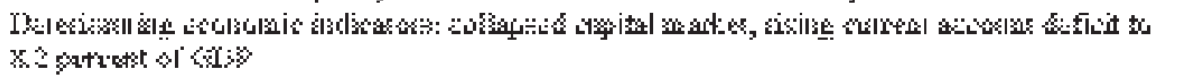 \\
\hline 19 & 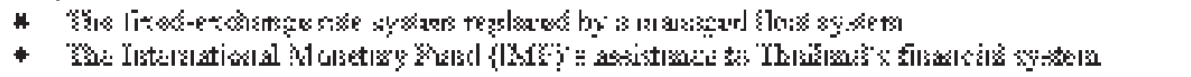 \\
\hline $198-19 \%$ & 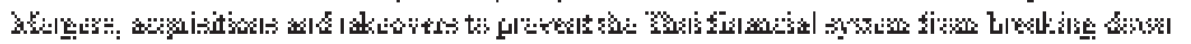 \\
\hline 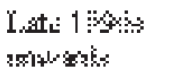 & 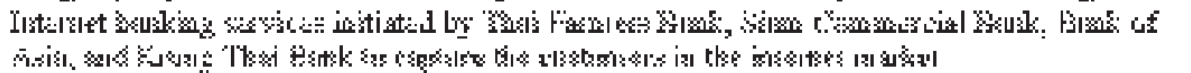 \\
\hline
\end{tabular}

the emergence of ATM service in the smart automation regime. The introduction of ATM services by Siam Commercial Bank in 1983 triggered the banks to invest in technology to build up their technological capabilities. In other words, it was a technology push that pressurised all the banks to enter into a high degree of competition to survive in the banking industry.

Table 3: Major banking services in Thailand

\begin{tabular}{|c|c|}
\hline Banking sea'vices & Key characteristics \\
\hline 1. Online services & $\begin{array}{l}\text { - } \quad \text { provide onlīne, real-täne transaction processing between bank branches } \\
\text { - } \quad \text { custoners are not restricted to transactions at account-opening branches }\end{array}$ \\
\hline $\begin{array}{l}\text { 2. Automated Teller Machine } \\
\text { (ATM) }\end{array}$ & $\begin{array}{l}\text { - replace the functions of tellers in cash receiving and dispensing, fund } \\
\text { transfer between accounts, balance enquiries, etc. } \\
\text { - provide convenient services unrestricted by banking hours }\end{array}$ \\
\hline 3. Point of Sale system (POS) & $\begin{array}{l}\text { - provide convenieat services by directly debitiag custoners' accoants af } \\
\text { the point of sale avoiding the need to carry cast } \\
\text { the complexities of asing the achine (teminal) are transferred to the } \\
\text { service providers } \\
\text { - a trend towards a cashless society }\end{array}$ \\
\hline 4. Phoné banking & $\begin{array}{l}\text { - provide easy and convenient access to account balance and other } \\
\text { information, i.e. interest rates, foreign exchange rates } \\
\text { provide the transfer of funds within and between accont holders or } \\
\text { payment of public utilities by telephone } \\
\text { credit card retailers can check the statns of the card by telephone }\end{array}$ \\
\hline 5. Internet baaking & $\begin{array}{l}\text { - provide customers an access and inçairy about their accounts as well as } \\
\text { allow customers to perform internet-based transactions (such as fund } \\
\text { transfer, e-cash card paymeat) from the castceners' workplace or loome }\end{array}$ \\
\hline
\end{tabular}


The widespread investment in technology to offer an array of EB services in Thailand began in the smart automation regime. In the late 1990s, electronicbased banking began to transform into Internet-based banking. The major banking services which are interesting and widely used in the Thai banking are shown in Table 3. This could be summarised as done in the table under five topics. Online services were introduced to facilitate customer contact at the lowest costs. Automation via ATM services played critical role in speedier response to this

Table 4:The major adoption of technology to improve technological capabilities

\begin{tabular}{|c|c|}
\hline E:Th & 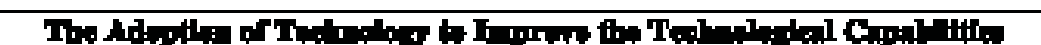 \\
\hline 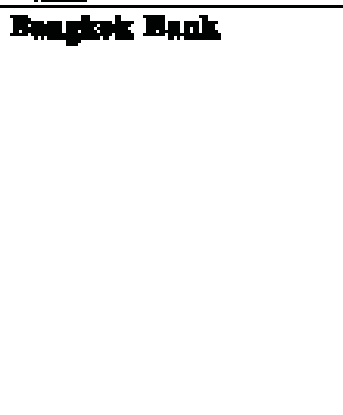 & 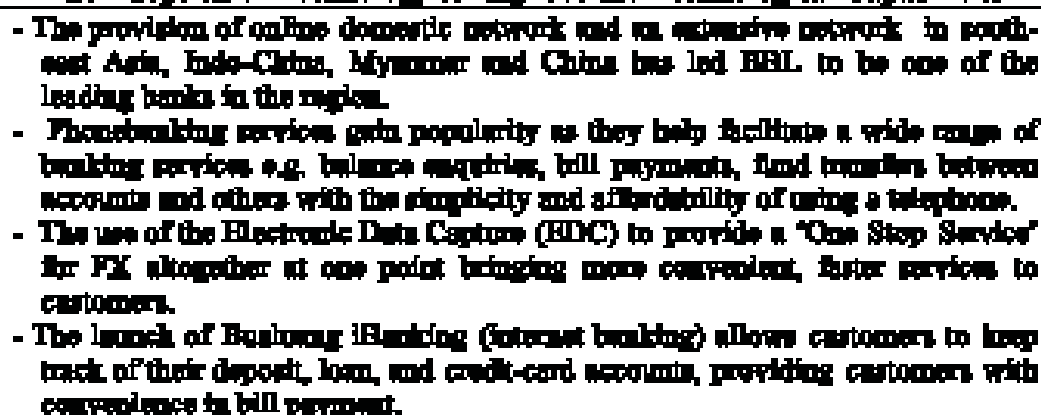 \\
\hline 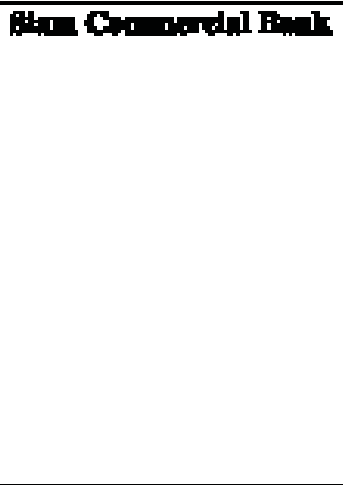 & 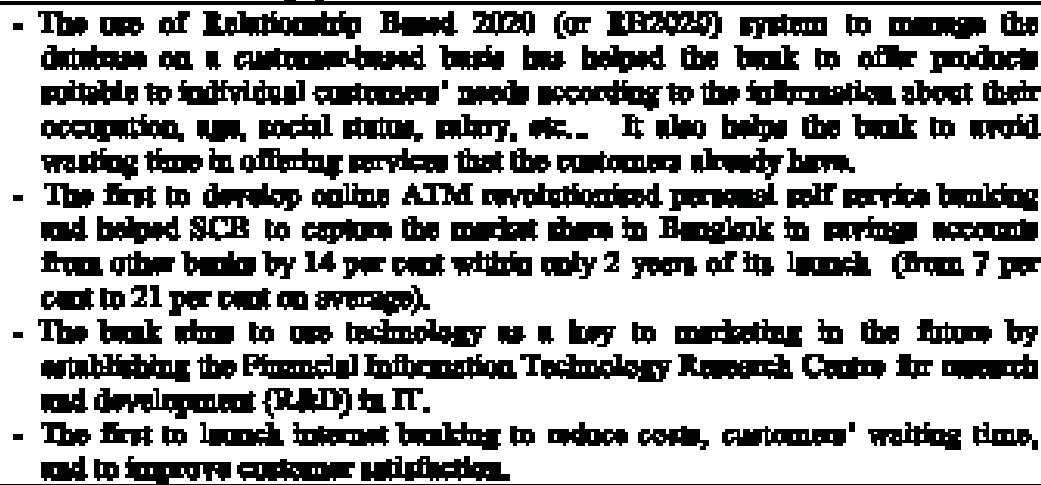 \\
\hline 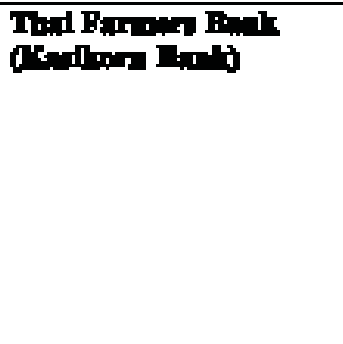 & 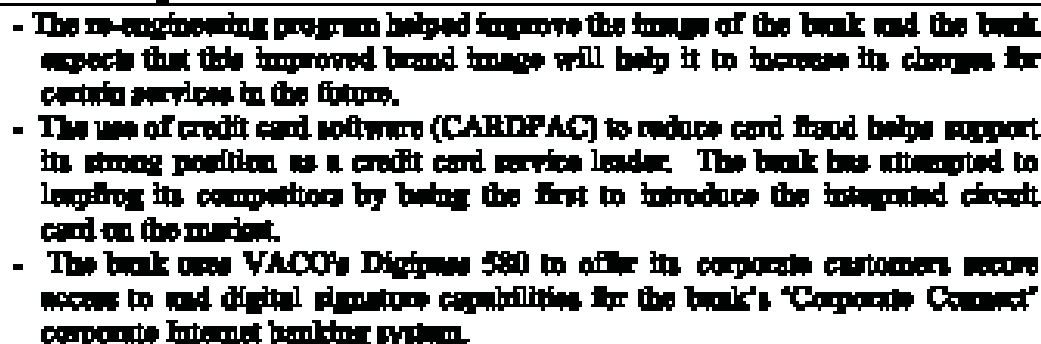 \\
\hline 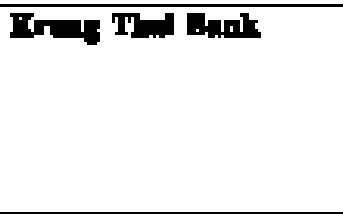 & 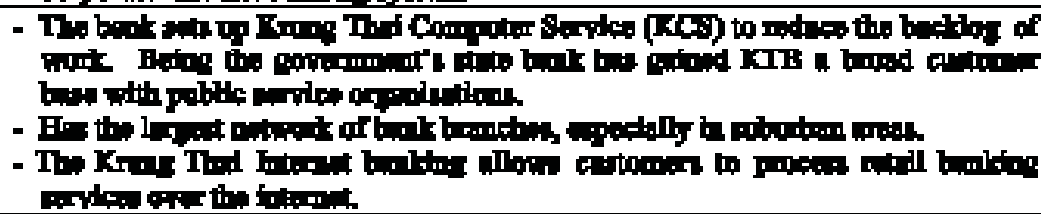 \\
\hline Biale of Aly & 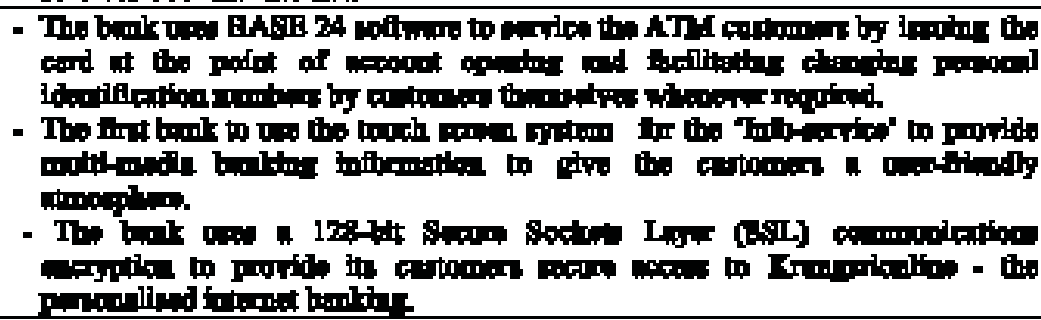 \\
\hline
\end{tabular}


critical cash and other service provisions without human contact. The other more sophisticated technology suc as internet banking evolved later.

The adoption of technology to improve the technological capabilities in the retail banking business is shown in Table 4 .

Our analysis of these banks adoption of IT shows clearly that the technology change was widespread, and very early as adoption of newer ways of doing things. The progression from online interface to internet and high-speed and from encrypting internet information shows that the major banks were leading in the adoption of technological change as pioneers.

\section{Case study analysis of Thai banks}

Is technological change evolutionary or revolutionary? This section distinguishes between the two technological regimes to see whether the change from the mass to the smart automation regime is evolutionary or revolutionary. The variables for measuring the change are similar to those employed by Buzzacchi et al. In order to do this, seven variables related to the change of technological regime are used as indicators. Among these, two variables (the adoption of mainframe computers and off-line batch processing) are concerned with the mass automation regime. The other five (the adoption of online real-time processing, automated teller machine (ATM), point of sale (POS), Phone banking, and personal computers $(\mathrm{PC})$ ) are concerned with the smart automation regime. See Table 5.

Following their attempts to show that there is a shift in technological regime, the analysis in the following table should be interpreted as follows. If the variables

Table 5: Analysis of technological change (evolutionary/revolutionary)

\begin{tabular}{|c|c|c|c|c|c|c|c|c|c|c|}
\hline \multirow[t]{2}{*}{ Variables } & \multicolumn{2}{|c|}{ Bampkak Benk } & \multicolumn{2}{|c|}{$\begin{array}{c}\text { Siam Coumeral } \\
\text { Bank }\end{array}$} & \multicolumn{2}{|c|}{$\begin{array}{c}\text { Thad Yarmers } \\
\text { (Kasikern) Beak }\end{array}$} & \multicolumn{2}{|c|}{ Krugg Thai Bawk } & \multicolumn{2}{|c|}{ Bask of Aysudgy } \\
\hline & Mass & Smart & Mass & Smart & Mass & Smant & Mass & Smart & Mass & Smart \\
\hline 1. Mainframe & $*$ & $\bullet$ & $\bullet$ & $\bullet$ & $*$ & - & $\bullet$ & $\bullet$ & $\bullet$ & $\bullet$ \\
\hline 2. Off-līe batch & - & - & $\bullet$ & - & $\bullet$ & - & $\bullet$ & - & $\bullet$ & $\bullet$ \\
\hline 3. Online & - & - & $\bullet$ & $\bullet$ & & $\bullet$ & N/A & $\bullet$ & N/A & $\bullet$ \\
\hline 4. ATM & $\mathrm{N} / \mathrm{A}$ & $\bullet$ & $\mathrm{N} / \mathrm{A}$ & $\bullet$ & $\mathrm{N} / \mathrm{A}$ & - & $\mathrm{N} / \mathrm{A}$ & - & $\mathrm{N} / \mathrm{A}$ & - \\
\hline 5. pos & N/A & $\bullet$ & $\mathrm{N} / \mathrm{A}$ & $\bullet$ & N/A & - & $\mathrm{N} / \mathrm{A}$ & $*$ & N/A & - \\
\hline Phone & $\mathrm{N} / \mathrm{A}$ & - & $\mathrm{N} / \mathrm{A}$ & - & $N / A$ & - & $\mathrm{N} / \mathrm{A}$ & - & $\mathrm{N} / \mathrm{A}$ & - \\
\hline banking & & & & & & & & & & \\
\hline 7. $\mathrm{PC}$ & $\mathrm{N} / \mathrm{A}$ & $\bullet$ & $\mathrm{N} / \mathrm{A}$ & $\bullet$ & $N / A$ & $\bullet$ & $\mathrm{N} / \mathrm{A}$ & • & $\mathrm{N} / \mathrm{A}$ & $\bullet$ \\
\hline
\end{tabular}

Note $: \bullet:$ The use of the variable in the stated technological regime

N/A : Not applicable since the technology has not yet been adopted within the stated regime.

Mass : Mass Automation Regime.

Smart : Smart Automation Regime. 
which represent the use of technology in the individual regime are solely employed in the mass or smart automation regime according to the aforementioned indicators, then this represents a shift in technological regime or exhibits a revolutionary characteristic. If not, they seem to be evolutionary, and thus question their argument.

The analysis shows that technological change in Thai banking is evolutionary for a number of reasons.

First, regarding the mass automation regime, all the banks used mainframe computers and off-line batch processing in accordance with Buzzacchi et al.'s definition. However, three out of the five major banks - Bangkok Bank, Siam Commercial Bank, and Thai Farmers Bank (Kasikorn Bank) - used online, realtime transaction processing within this regime, in contrast to what they suggested, i.e., the exclusion of online from this regime. In the industry, Bangkok Bank was the first bank to use online in 1970 for use in credit processing and accounting entries. With Bangkok Bank's leading role in online technology, Siam Commercial Bank caught up Bangkok Bank in the same year by offering an online service to enable customers to make deposits or withdrawals at any branch. This was mainly aimed at catching up with Bangkok Bank rather than facilitating accounting functions within the bank. In the same year, Thai Farmers Bank (Kasikorn Bank) followed the leading banks by gradually developing a front-office, online service. The other two banks namely the Krung Thai Bank and Bank of Ayudhya also tried to catch up, but rather, they lagged behind.

It can be seen that the online service was carried out in parallel with off-line batch processing for deposits and withdrawal transactions, showing that online, real-time processing and off-line, batch processing can co-exist in the same technological regime, in sharp contrast to Buzzacchi et al.'s characterisation. Second, regarding the smart automation regime, the variables representing the adoption of technology - online, real-time transaction processing, ATM, Point of Sale (POS), Phone Banking, and Personal Computers - seem to be in line with Buzzacchi et al.'s definition.

However, there are exceptions in that the the mass automation regime did not result in the withdrawal of mainframe computers and off-line, batch processing. The mainframe computers were still in use by all major banks. For example, in the early 1970s, Bangkok Bank installed an IBM 360/30 mainframe computer at its headquarter to handle the automation of cash deposits and withdrawal functions of savings accounts. Siam Commercial Bank also used a mainframe computer system 4331 for branch development tasks in 1971. In 1979, Siam Commercial Bank introduced the Singer mainframe computer system 10 to operate online systems for customer services for deposits and withdrawals at its Chidlom branch. Thai Farmers Bank (Kasikorn Bank) also continued to use the Burroughs and IBM 308X mainframe with the operating system of MVS/XA (MultiVirtual System/Extended Architecture) for online data processing. Its Business Development Information system for its reengineering program also ran on OS/2 
based Pentium PCs linked to the mainframe computer system. Krung Thai Bank used Tandem, IBM, and Philips mainframe computers during this regime and Bank of Ayudhya also used the mainframe computer system together with NEC Local Area Network (LAN) 4700 as an enterprise server for branch operations.

For the off-line, batch processing used by all 5 major banks during this regime, Bangkok Bank developed the system 434 batch processing for deposits, credit, accounting, and back-office functions in parallel with the online system.

Siam Commercial Bank also carried out batch processing for reports in parallel with the operation of the online system at its Chidlom branch. Thai Farmers Bank ran batch processing for back-office banking processes to calculate interest and for accounting transaction entries, as did Bank of Ayudhya. In addition, since Bank of Ayudhya was constrained by limited funds for investment when purchasing new equipment, it did not throw away the existing system and turned to the new and open system of UNIX. The existing system was still capable of handling transactions, representing the technological choice in selecting new technology to be based on an existing technology for reasons of compatibility.

The analysis shows that there is no shift in technological regime. To put it another way, the technological change in the Thai banking industry is not revolutionary because if it were, there should be no further use of mainframe computers and off-line batch processing within the smart automation regime (the position of Buzzachi et al.). As far as the analysis was concerned, the technological trajectory of Thai banking did not take a different path from the past because the mainframe computers and off-line batch processing were still used during the smart automation regime.

Third, the technology used in the mass and smart automation regime was not consistent with that of Buzzacchi et al.'s definition. In the case of Thai banking, the online, real-time transaction processing which they defined as the technology used in the smart automation regime was already used in the mass automation regime. Even within the smart automation regime itself, there were still the continuous use of the mainframe computers and off-line batch processing, as well as the use of the technologies - Electronic Banking (EB) services - defined as appropriate in this regime.

Can cumulative learning be used in smart automation regime? This sub-section explores whether there is any disruption of cumulative learning with a change in regime. As stated in Section 2, Buzzacchi et al. argues that the shift from the mass automation regime to the smart automation regime leads to a substantial devaluation of the stock of knowledge and skills accumulated by firms in the previous regime. Two variables - the continuity of employment of the existing personnel and new employees - related to the concept of cumulative learning are used as indicators in order to signify whether their argument is valid in the case of Thai banking. 
- The continuity of employment of the existing personnel means the continued employment of personnel from the mass automation regime in the smart automation regime. If the existing personnel can undertake the EB services in the subsequent regime through reinforcing their skills with new training programs or new knowledge, then this represents competence-enhancing.

- New employees means the hiring of new personnel to fit the smart automation regime. If the banks have to hire a new set of employees to undertake EB services in the smart automation regime with no help from existing personnel, then this represents competence-destroying.

It should be noted that Tushman and Anderson have not developed any variable to determine competence-enhancing or competence-destroying capabilities. Neither have Buzzacchi et al. developed any variables. These cannot be determined solely by quantitative methodologies because the number of increasing or decreasing personnel does not directly represent competenceenhancing or competence-destroying capabilities since personnel may leave the

Table 6: Analysis of cumulative learning through the technological regime

\begin{tabular}{|c|c|c|c|c|c|c|c|c|c|c|}
\hline \multirow[t]{2}{*}{ Variables } & \multicolumn{5}{|c|}{$\begin{array}{l}\text { Mass Autom ation Regime } \\
1960 \mathrm{~s}-1970 \mathrm{~s}\end{array}$} & \multicolumn{5}{|c|}{$\begin{array}{l}\text { Smart Autemation Regime } \\
\text { Early } 1970 \text {, onwards }\end{array}$} \\
\hline & BBL & $\mathrm{SCB}$ & TFB & KTB & BAY & BBL & $\mathrm{SCB}$ & TFB & KTB & $\mathrm{BAY}$ \\
\hline $\begin{array}{l}\text { 1. The continaity of } \\
\text { employment of the } \\
\text { existing personel } \\
\text { 2. New employees }\end{array}$ & \multicolumn{5}{|c|}{$\begin{array}{l}\text { - The employment of existing } \\
\text { personnel is to enable them to } \\
\text { operate and maintain the computer } \\
\text { system. } \\
\text { - New employment is to replace } \\
\text { nommal staff tumover. }\end{array}$} & \multicolumn{5}{|c|}{$\begin{array}{l}\text { - The continaed employment of } \\
\text { existing personnel is to boild op } \\
\text { skills and knowiedge in order to crery } \\
\text { oot EB services. } \\
\text { - There is a need for new employees } \\
\text { with aew skills for specialised and } \\
\text { sophisticated banking busineas. }\end{array}$} \\
\hline
\end{tabular}

Note : $-\quad$ : the use of the variable in the stated technological regime.

BBL : the Bangkok Bank;

SCB : the Siam Commercial Bank;

TFB : The Thai Farmers Bank (Kasikorn Bank);

KTB: the Krung Thai Bank;

BAY : the Bank of Ayudhya.

bank to move to other banks, retire, etc. Detailed staff histories would be necessary to determine whether the reason for leaving related only to the change of regime. However, the variables used here are not a solid measure but are suggested in order to perform a qualitative analysis: see Table 6 .

The analysis shows that cumulative learning in the mass automation regime can be used in the smart automation regime for the following reasons.

First, regarding the mass automation regime, the existing personnel were able to perform system operation and maintenance tasks. In the initial phase of IT adoption, working through vendor relationships (learning by interacting with suppliers) was important because the banks lacked a strong IT team. So it was necessary to have technical links to support the efficient use of new technologies. 
In other words, the learning in this regime can be regarded as a process of continuous problem-solving and developing a system to operate properly. For example, Bangkok Bank (BBL) received training support from the supplier - IBM - during its first use of computer technology. The accounting personnel who already had background knowledge in accounting and banking systems were trained to be programmers or systems analysts to operate and maintain the new computer system installed by the vendor.

Siam Commercial Bank (SCB) also operated with technical advice from vendors like IBM and Hitachi. The development of the system gradually evolved through the close cooperation with IBM systems representatives to help the bank personnel resolve any technical problems. The same was true of Thai Farmers Bank (Kasikorn Bank) as IBM not only provided training for bank personnel when selling the software, enabling the system to be maintained through the skills transfer. However, the capabilities of extending, developing, or adding features to obtain optimum use are characterised as learning by doing. Although there was a great deal of dependency on the vendors (i.e. Krung Thai Bank on Philips and Digital technology; Bank of Ayudhya on IBM and TANDEM technology), bank personnel still had to study from system manual themselves in order to learn gradually how to improve it because all the software purchased from abroad had to be modified to suit the environment and regulations of the Thai banking system.

New employment in the mass automation regime was mainly to replace existing staff as well as for newly created posts. Since the adoption of IT, the 5 major banks had no lay off policy for fear of anti-computer technology protests from the existing personnel. However, the IT did reduce manual work, so the bank transferred any excess personnel to undertake the other banking functions or to fill posts in new branch operation.

Second, in the smart automation regime, the continued employment of existing personnel was to build up skills and knowledge necessary to carry out the EB services. They were aided by the training program to enhance competencies in the use of new IT. This is evidenced by the continued employment of the existing personnel in the smart automation regime who had joined the bank in the days of the mass automation regime. This shows competence-enhancing along with technological change ${ }^{1}$. If the smart automation regime really resulted in competence-destroying, the existing personnel should not be able to continue the EB services since Buzzacchi et al. claimed that there seemed to be no positive relationship between the EB services and the knowledge in the previous regime.

Although most of the variables for technology use (ATM, POS, Phone Banking, and PC as shown in Table 5) began this regime, they were not a totally new technological concept per se, but a functional improvement of the existing technology, since there is an interrelationship between the two technologies.

1 These are the examples in the technological aspect but there may be some other reasons for the continued employment like patronage, personal reasons for the mass of workers. 
Indeed, there seems to have been a carryover of learning from one system to another. It is argued that the basic knowledge of off-line, batch processing could be applied to the online real-time processing, but there was not much advance in terms of application theory.

The online, real-time processing or ATM was an improved technology service from the basic knowledge of deposits and withdrawals, but its novelty was only peripheral. Without the online, real-time processing operated before in the mass automation regime (as seen in Table 5 for Bangkok Bank, Siam Commercial Bank and Thai Farmers (Kasikorn Bank), the ATM in the smart automation was not operable since it was based on the concept of online networking. The mainframe computers were still used to operate online systems using message switching, allowing for the interbranch transactions of deposits and withdrawals. In addition, the use of PCs for office automation in this regime still had to be based on the mainframe, centralised, data processing system by using network switching between the terminals and the host computers, facilitating deposits, withdrawals transactions, and balance enquiries.

Bangkok Bank built up its strong IT team by training the existing personnel in knowledge of both the system and the banking products so that they could specialise in handling both the system and service of the business effectively. For Krung Thai Bank, during the transition from off-line, batch processing to online, real-time processing, the existing personnel who had written the programs for batch processing (with the aid of some training) also wrote the programs for the online processing. Siam Commercial Bank underlined the importance of the 'learning organisation' by preparing not only the technology, but also the personnel to be ready for competition with foreign banks under the period of financial liberalisation (1990s, onwards). The banks in this regime still needed cooperation from the suppliers to support the skills of their personnel (i.e. Thai Farmers Bank with the support of Burroughs and IBM for online programming).

However, the effort to build up its own IT workforce (i.e. Thai Farmers Bank's system engineering department, Krung Thai Bank's KCS, Bank of Ayudhya's in-house development) was greatly emphasised. The bank's in-house technology helped lower costs and increased efficiency since the banking technicians could receive information from, and coordinate with, bank personnel. The banks also sent their personnel to learn more about banking technologies in the advanced countries and to bring the knowledge back to foster their own system development department (i.e. to Hong Kong for the system of Systematic and Hogan; U.S.A. in the area of application development).

In the smart automation regime, there was a need for new employment patterns with new skills (learning by searching) for specialised and sophisticated banking business. The recruitment of new personnel was likely in areas where the banks lacked technological capabilities. It is argued that the knowledge of system development is partly tacit and embodied in personnel. This tacit knowledge 
was essential for further building-up of technological capabilities, so the bank had to solve the problem by purchasing IT experts (learning by searching) and software (i.e. credit processing function), instead of developing these itself. This type of learning by Krung Thai Bank included the search for foreign experts to speed up software development to catch up with other banks. Krung Thai Bank's learning, thus, seemed to be pushed by internal problems and was rather different from the other banks' learning, which put more emphasis and effort intensity into developing the system by self-learning.

Third, it should be noted that the continuous employment of existing personnel possessing some level of skill and knowledge of the current technology seemed necessary so that they could help new personnel to absorb the new knowledge embodied in new technology. In other words, path dependency still matters because the knowledge is partly tacit for internal learning to happen. The importance of path dependency does not only concerns technological capabilities, but also the managerial capabilities to deal with the socio-economic and market conditions to enable competencies to be enhanced. These are capabilities that intertwine and cannot be built up in isolation by new personnel since these capabilities are the complementary assets necessary for building up technological capabilities under conditions of dynamic competition.

\section{Conclusions}

The study assumes the essence of the learning process is cumulative development, which is the central concept of accumulating technological capabilities. Regarding the learning concepts in the context of the Thai banking industry, the learning mechanisms to strengthen the bank's technological capabilities are mainly 'learning by doing' (e.g. the case of Bangkok Bank) and 'learning by interacting with suppliers' (e.g. the case of Siam Commercial Bank, Thai Farmers Bank (Kasikorn Bank), Krung Thai Bank and Bank of Ayudhya). In the era of banking modernisation (late, smart automation regime), the banks realise the necessity to adopt other learning mechanisms like learning by training and learning by searching to build up human resources, as these are concerned with capability accumulation.

Interestingly enough, this conclusion approaches the thinking of the learning process. The study suggests that continuous learning is essential but the banks should not place too much dependence on suppliers which may limit its own capacity to develop capabilities. Today, competitive contention in the banking industry challenges the banks to leverage their IT strategy to offer banking products to meet their customers' needs. Banks compete by investing in technology to speed up the banking services and improving operational efficiency of banking operations. The offer of banking services like Home Banking services, VDO Banking, Internet banking, and mobile banking (mobile commerce) shows that 
the banks had adopted technology to compete in service performance, which enabled them to build up their technological capabilities.

The empirical analysis shows that the technical change in Thai banking is evolutionary and the cumulative learning from the mass automation regime can be used in the smart automation regime. This has shown that the conceptual model of Buzzacchi et al. arguing that there is a discontinuity between the mass and smart automation regime, and thus the cumulative learning in the mass automation regime cannot be used in the smart automation regime, is not valid in the case of Thailand. The argument that there is a substantial devaluation of the stock of knowledge and skills accumulated by firms in the mass automation regime is not applicable to the case of Thai banking. The empirical analysis shows that there is a cumulative development of learning processes by the personnel who cross from one regime to the other which shows that cumulative technological knowledge is not cancelled out, but present.

Therefore, it should not be considered as a weak link, but rather, a strong evolutionary link from the mass automation regime towards the smart automation regime. The continuity of cumulative learning shows that it is not competencedestroying but competence-enhancing between the two regimes. Hence, the learning of new technological capabilities in Thai banking seems to be in accordance with the third concept of learning, that is, learning is a process of enhancing the stock of knowledge in an evolutionary manner.

The study has made a small contribution to technological change literature linked to evolutionary and revolutionary issues, which is a missing element in the literature on learning concepts. Technological learning seems to have a close relationship with organisational learning. However, the latter is outside the scope of the present study. It would, therefore, be interesting if future research could explore the technological change and its relationships within organisational structures in the banking industry to understand if there is an interdependent relationship between technological learning and organisational learning.

Acknowledgment: The author acknwledges with thanks the revisions to the paper following the blind review of the paper. The remaining errors are the responsibility of the author.

Author Statement. Jarunee wonglimpiyarat is Certified Public Accountant (CPA) and Science Policy Researcher at the Ministry of Science and Technology Thailand. Her main research area is financial innovations. Her publications include the Barclaycard Case Study in 'Exploring Corporate Strategy' (Europe's best-selling strategy textbook) by Gerry Johnson and Kevan Scholes Strategies of Competition 
in the Bank Card Business. The author wishes to thank the anonymous reviewer as well as the editors of the Journal for extensive revisions of the original version fo this paper.

\section{References}

Adler, P., and Clark, K., (1991). 'Behind the Learning Curve: A Sketch of the Learning Process', Management Science, Vol. 37(issue no. 3): 267-281.

Amsden A. and Hikino, T., (1993). 'Borrowing Technology or Innovating: An Exploration of Two Paths to Industrial Development', in Fransman, M. and King, K. (Editors), Technological Capability in the Third World, MacMillan Press, London.

Arrow, K., (1962). 'The Economic Implications of Learning by Doing', Review of Economic Studies, Vol. 29: 155-73.

Barras, R., (1990). 'Interactive innovation in financial and business services: The vanguard of the service revolution', Research Policy, Vol. 19: 215-237.

Bell, M. and Scott-Kemmis, D., (1985), Who learned what by doing what:: a reexamination of 'learning by doing' in the air flame and shipbuilding industries, mimeo, Science Policy Research Unit, University of Sussex.

Bell, M., (1984). 'Learning and the Accumulation of Industrial Technological Capacity in Developing Countries', in Fransman, M. and King, K. (Editors), Technological Capability in the Third World, MacMillan Press, London.

Buzzacchi, L., and Colombo, M., (1993). 'Technological regimes and innovation in services: the case of the Italian banking industry', Research Policy, Vol. 24: 151-168.

Bessant, J., and Buckingham, J., (1993). 'Innovation and Organizational Learning : the Case of Computer-Aided Production Management', British Journal of Management, Vol. 4: 219-234.

Bell, M., and Pavitt, K., (1993). 'Technological Accumulation and Industrial Growth: Contrasts Between Developed and Developing Countries', Industrial and Corporate Change, Vol. 2(issue no. 2): 185-203.

Cohen, W. and Levinthal, D., (1990). 'Absorptive Capacity: A New Perspective on Learning and Innovation', Administrative Science Quarterly, Vol. 35: 128-152.

Dosi, G., Freeman, C., (1994). 'The Process of Economic Development: Introducing some Stylized facts and Theories on Technologies, Firms and Institutions', Industrial and Corporate Change, Vol. 3(1): 1-45.

Dahlman, C., and Fonseca, F., (1987). 'From Technological Dependence to Technological Development: The Cases of the USIMINAS Steel Plant in 
Brazil', in Katz, J., (Editor), Technological Generation in Latin American Manufacturing Industries, Macmillan Press, London.

Dahlman, C., and Westphal, L., (1982). 'Technological Effort in Industrial Development: A Survey', in F. Stewart and J. James (Editors), The Economics of New Technology in Developing Countries, Frances Pinter, London.

Freeman, C., and Perez, C., (1988). 'Structural crises of adjustment, business cycles and investment behaviour, in Dosi G., and C. Freeman (Editors), Technical Change and Economic Theory, Pinter Publishers, London.

Hobday, M., (1995). Innovation in East Asia: The Challenge to Japan, Edward Elgar, Cheltenham.

Lall, S., (1994). Developing Countries as Exporters of Technology: A First Look at the Indian Experience, Macmillan, London.

Lall, S., (1994). 'Technological Capabilities', in J. Salomon et al. (Editors), The Uncertain Quest: Science Technology and Development, United Nations University Press, Tokyo, Japan.

Malerba, F., (1992). 'Learning by Firms and Incremental Technical Change', The Economic Journal, Vol. 102: 845-859.

Mansel, R., and Wehn, U., (1998). Knowledge Societies : Information Technology for Sustainable Development, Oxford University Press, Oxford.

Nelson, R., and Winter, S., (1982). An Evolutionary Theory of Economic Change, Harvard University Press, Cambridge.

Nelson, R., and Winter, S., (1977), 'In Search of a Useful Theory of Innovation', Research Policy, Vol. 6.

Pavitt, K., (1986). 'Technology, Innovation, and Strategic Management', in J. McGee and H. Thomas (Editors), Strategic Management Research, A European Perspective, John Wiley \& Sons, Chichester.

Rosenberg, N., (1982). 'Learning by Using', in Rosenberg, N. (Editor), Inside the Black Box: Technology and Economics, Cambridge University Press, Cambridge.

Teece D., and Pisano, G., (1994). 'The Dynamic Capabilities of Firms: an Introduction', Industrial and Corporate Change, Vol. 3(issue no. 3): 537556.

Tushman, M., and Anderson, P., (1986). 'Technological Discontinuities and Organization Environments', in A. Pettigrew (Editor), The Management of Strategic Change, Blackwell, Oxford.

Von Hippel, E., (1988). The sources of innovation, Oxford University Press, New York, New York.

Von Hippel, E., and Tyre, M., (1995). 'How learning by doing is done: problem identification in novel process equipment', Research Policy, Vol. 24: 1-12.

Von Tunzelmann, G.N., (1995). Technology and Industrial Progress, Edward Elgar, Aldershot. 